MARTA J. SKRODZKA

ANNA SZAFRANEK

https://doi.org/10.33995/wu2021.2.3

\title{
Ocena roli wyspecjalizowanych centrów mediacji na przykładzie Wydziału Pozasądowego Rozwiązywania Sporów w Biurze Rzecznika Finansowego
}

Instytucja mediacji - jednej z alternatywnych metod rozwiqzywania sporów, cieszy się stałym wzrostem zainteresowania, zarówno na gruncie prawa, jak i w praktyce. Z poczqtkiem XXI wieku w Polsce zaczęły powstawać różne ośrodki mediacyjne specjalizujące się w pozasqdowym rozwiq̨zywaniu sporów przedmiotowq metodq. W zwiqzku z powyższym pojawiajq się pytania o potrzebę istnienia, funkcjonowania i o rolę wyspecjalizowanych centrów mediacji - ośrodków świadczacych usługi w ramach pozasqdowego rozwiqzywania sporów w postaci postępowania mediacyjnego w ściśle określonej kategorii spraw (specjalizacja przedmiotowa). Częściowej odpowiedzi na tak sformułowane pytania dostarcza najnowsza analiza badania przeprowadzonego przez autorki niniejszego artykułu wśród mediatorów zatrudnionych w Wydziale Pozasqdowego Rozwiqzywania Sporów przy Rzeczniku Finansowym - a więc podmiocie, który w praktyce stosuje pozasqdowe procedury rozwiqzywania sporów w określonych kategoriach spraw. Przedmiotowe badanie pozwala również na realizację zasadniczego celu artykułu, jakim jest weryfikacja stanowiska mediatorów (na przykładzie opinii mediatorów zatrudnionych w Biurze Rzecznika Finansowego] w kwestii potrzeby funkcjonowania wyspecjalizowanych centrów mediacji w Polsce.

Słowa kluczowe: ADR, mediacja, pozasądowe rozwiązywanie sporów, polubowne rozwiązywanie sporów, Rzecznik Finansowy, spory na rynku finansowym. 


\section{Wprowadzenie}

Począwszy od lat 90. XX wieku można zauważyć w Polsce stały wzrost zainteresowania ${ }^{1}$ alternatywnymi w stosunku do sądu (lub, jak wskazują niektórzy autorzy, uzupełniającymi wymiar sprawiedliwości ${ }^{2}$ ] metodami rozwiązywania sporów (ang. Alternative Dispute Resolution, dalej ADR J, w tym jedną z podstawowych - mediacja. Pomimo braku definicji legalnej terminów mediacja i ADR w polskim porządku prawnym oraz podnoszonych w literaturze przedmiotu wạtpliwości terminologicznych odnoszących się do pojęcia ADR (zwłaszcza na gruncie teorii prawa) ${ }^{3}$, uprawnionym wydaje się stwierdzenie, że etymologicznie mediacja wywodzi się od greckiego słowa medos (pośredniczący, neutralny, nieprzynależny do żadnej ze stron) oraz łacińskiego mediatio (pośrednictwo) i może być definiowana jako postępowanie pozasąowe, w którym neutralna, odpowiednio do tego przygotowana osoba trzecia wypracowuje wraz ze stronami rozwiązanie w związku z powstałym pomiędzy nimi sporem (konfliktem) ${ }^{4}$.

Pomimo że idea mediacji jest znana i praktykowana na świecie od tysięcy lat ${ }^{5}$, w Polsce znalazła zastosowanie w prawie dopiero za sprawą prof. Leona Petrażyckiego, który na przełomie XIX i XX

1. Taki wniosek można wywodzić z liczby spraw skierowanych do mediacji przez sądy powszechne (rejonowe i okręgowe) w ostatnim dziesięcioleciu. Jak wynika z danych statystycznych zebranych i opracowanych przez Ministerstwo Sprawiedliwości, w roku 2013 sądy skierowały do mediacji 13370 spraw (na 2710 600, w których przeprowadzenie postępowania mediacyjnego było możliwe), przy czym w ramach skierowanych spraw przeprowadzono mediację w 3836 przypadkach; zaś już w roku 2016 sądy przekazały mediatorom 24105 sporów (na 2566177 możliwych), z czego w 5246 udało się przeprowadzić postępowanie mediacyjne.Z danych za rok 2019 wynika, że w 2459950 sprawach, w których możliwe było przeprowadzenie mediacji, sądy zdecydowały się oddać 30828 sporów pod mediację, a w 8204 z nich przeprowadzono postępowanie mediacyjne. Oznacza to, że wskaźnik mediacji - czyli odsetek spraw skierowanych do mediacji w stosunku do wszystkich spraw wpływajacych do sądów, w których mediacja może być zastosowana - wzrósłz poziomu 0,49\% w 2013 r., przez 0,95\% w 2016 r. do 1,25\% w 2019 r. (por.: https://www.gov.pl/web/sprawiedliwosc/dane-statystyczne-dotyczace-mediacji [dostęp: 26.02.2021]]). Wzrost zainteresowania problematyką ADR można wywieść również z rosnącej liczby prowadzonych badań i projektów naukowych w tym zakresie, a w związku z tym i z liczbą publikacji.

2. Por. m.in.: R. Morek, ADR - w sprawach gospodarczych, CH Beck, Warszawa 2004, s. 73; A. Zienkiewicz, Studium mediacji. Od teorii ku praktyce, Difin, Warszawa 2007, s. 227-231; A. Zienkiewicz, Mediacja jako forma wymiaru sprawiedliwości, „Arbitraż i mediacje” 2013, nr 4, Warszawa 2013, s. 101-115; M. Masternak-Kubiak, Komentarz do art. 175 Konstytucji RP, [w:] Konstytucja Rzeczypospolitej Polskiej, [red.] M. Haczkowska, Lex online 2019.

3. Zob. m.in.: E. Gmurzyńska, Mediacja w sprawach cywilnych w amerykańskim systemie prawnym. Zastosowanie w Europie i w Polsce, CH Beck, Warszawa 2007, s. 8-11; S. Pieckowski, Mediacja gospodarcza, Difin, Warszawa 2015, s. 23-28; K. Weitz, K. Gajda-Roszczynialska, Alternatywne metody rozwiqzywania sporów ze szczególnym uwzględnieniem mediacji, [w:] Mediacja w sprawach gospodarczych. Praktyka-teoria-perspektywy, [red.] A. Torbus, Ministerstwo Gospodarki, Warszawa 2015, s. 11-24; M. Araszkiewicz, K. Płeszka, Pojęcie alternatywnego rozwiqzywania sporów, [w:] Mediacja. Normy, teoria, praktyka, [red.] K. Płeszka, J. Czapska, M. Araszkiewicz, M. Pękala, Wolters Kluwer, Warszawa 2017, s. 45-159; R. Flejszar, K. Gajda-Roszczynialska, Alternatywne metody rozwiqzywania sporów ze szczególnym uwzględnieniem mediacji - postępowanie cywilne, [w:] Mediacja. Normy ..., s. 163-174.

4. Por. m.in.: E. Gmurzyńska, op. cit., s. 30-34; K. Weitz, K. Gajda-Roszczynialska, op. cit., s. 35-43.

5. Szerzej na temat historii i rozwoju mediacji w różnych systemach prawnych zob. np.: A. Korybski, Alternatywne rozwiqzywanie sporów w USA. Studium teoretycznoprawne, Wydawnictwo UMCS, Lublin 1993, 69-102; E. Gmurzyńska, op. cit., s. 1-11. 
wieku wprowadził ją niejako pośrednio ${ }^{6}$ do teorii prawa, głosząc ideę sprawiedliwości naprawczej? Pierwsze regulacje prawne polskiej instytucji mediacji zostały skonstruowane w latach 90. XX wieku, kiedy przedmiotowa idea została unormowana w $1991 \mathrm{r}$. w przepisach odnoszących się do prawa pracy $^{8}$. Następnie w 1997 r. w systemie prawa karnego w: Kodeksie karnym ${ }^{9}$ i Kodeksie postępowania karnego ${ }^{10}$ oraz w odniesieniu do dorosłych sprawców przestępstw i w stosunku do nieletnich rozporządzeniami Ministra Sprawiedliwości z 1998 i 2001 roku ${ }^{11}$. Należy przy tym podkreślić, że wprowadzenie instytucji mediacji do prawa karnego było możliwe dzięki dużemu zaangażowaniu w propagowanie tej idei przez Stowarzyszenie Penitencjarne „Patronat”. Współpracowało ono z zachodnimi ośrodkami zajmującymi się mediacją i stworzyło Zespół ds. Wprowadzenia Mediacji w Polsce ${ }^{12}$, który następnie opracował przedmiotowe przepisy. Wspomniany Zespół, po przekształceniu w Stowarzyszenie Polskie Centrum Mediacji, przyczynił się m.in. do unormowania postępowania mediacyjnego także w sferze prawa cywilnego oraz doprowadził do powołania Społecznej Rady do spraw Alternatywnych Metod Rozwiązywania Sporów przy Ministrze Sprawiedliwości ${ }^{\bigotimes}$. Obecnie instytucja mediacji jest uregulowana we wszystkich dziedzinach prawa w tym, poza wymienionymi już, także na gruncie prawa administracyjnego ${ }^{13}$.

Wzrost zainteresowania instytucją mediacji, poprzez powstanie uregulowań prawnych oraz jej upowszechnianie w praktyce spowodowały, że już na początku XXI wieku w Polsce zaczęły powstawać różne ośrodki mediacyjne specjalizujące się w pozasądowym rozwiązywaniu sporów

6. Nie nazwał jej bowiem wprost mediacją.

7. Leon Petrażycki uznawany jest w literaturze za prekursora mediacji. Zob.: L. Petrażycki, O nauce, prawie i moralności. Pisma wybrane, PWN, Warszawa 1985, s. 1 i nast.; K. Bednarz, Koncepcja sprawiedliwości naprawczej wg Leona Petrażyckiego a mediacja w procesie cywilnym, [w:] Prawo i nauka w pogladach Leona Petrażyckiego, [red.] D. Gil, Ł. Pikuła, Wydawnictwo KUL, Lublin 2013, s. 161 i nast.

8. Ustawa z dnia 23 maja 1991 r. o rozwiązywaniu sporów zbiorowych (Dz. U. 1991, nr 55, poz. 236). Wskazany publikator aktu prawnego pochodzi z okresu, gdy wprowadzono do niego przepisy o mediacji.

9. Ustawa z 6 czerwca 1997 r. - Kodeks postępowania karnego (Dz. U. 1997, nr 88, poz. 553). Wskazany publikator aktu prawnego pochodzi z okresu, gdy wprowadzono do niego przepisy o mediacji.

10. Ustawa z 6 czerwca 1997 r. - Kodeks postępowania karnego (Dz. U. 1997, nr 89, poz. 555). Wskazany publikator aktu prawnego pochodzi z okresu, gdy wprowadzono do niego przepisy o mediacji.

11. Rozporządzenie Ministra Sprawiedliwości z 14 sierpnia 1998 r. w sprawie warunków, jakim powinny odpowiadać instytucje i osoby uprawnione do przeprowadzenia mediacji, zakresu i warunków udostępniania im akt sprawy oraz zasad i trybu sporządzania sprawozdania z przebiegu i wyników postępowania mediacyjnego (Dz. U. 1998, nr 111, poz. 701). Rozporządzenie Ministra Sprawiedliwości z 18 maja 2001 r. w sprawie postępowania mediacyjnego w sprawach nieletnich (Dz. U. 2001, nr 56, poz. 591). Wskazane publikatory aktów prawnych pochodzą z okresu, gdy wprowadzono do nich przepisy o mediacji.

12. Historia mediacji, https://www.lublin.so.gov.pl/historia-mediacji,m,mg,282,303 [dostęp: 26.02.2021], Historia PCM, https://mediator.org.pl/o-nas/historia-pcm/ [dostęp: 26.02.2021].

13. Szerzej na ten temat zob. np.: M. J. Skrodzka, A. Zemke-Górecka, Instytucja mediacji w polskim porzqdku prawnym - jej rozwój i przyszłość w sporach z zakresu prawa cywilnego, „Palestra” 2019, nr 11-12, s. 263-273. 
przedmiotową metoda ${ }^{14}$. Wskazane podmioty prowadza jednak - co do zasady - postępowania mediacyjne we wszystkich kategoriach spraw, nie ograniczając ich tylko do jednej wybranej ${ }^{15}$.

Jednak koniec XX i początek XXI wieku to nie tylko rozwój mediacji. Postęp i szybkie tempo zmian, m.in. polityczno-społeczno-gospodarczych, oraz nieprzewidziane sytuacje, jak np. ogólnoświatowa pandemia wywołana wirusem SARS-CoV-2, wymuszają zarówno na społeczeństwie, jak i na podmiotach prowadzạcych różnego rodzaju działalność gospodarczą czy non-profit zmiany, w tym konieczność oferowania usług ściśle określonych - adresowanych do wąskiej grupy odbiorców.

W związku z powyższym pojawiają się pytania o potrzebę istnienia, funkcjonowania i rolę wyspecjalizowanych centrów mediacji - ośrodków świadczących usługi w ramach pozasądowego rozwiązywania sporów w postaci postępowania mediacyjnego w ściśle określonej kategorii spraw (specjalizacja przedmiotowa). Możliwej odpowiedzi na tak sformułowane pytanie dostarcza najnowsza analiza badania przeprowadzonego przez autorki niniejszego artykułu wśród mediatorów zatrudnionych w Wydziale Pozasądowego Rozwiązywania Sporów (dalej WRS, Wydział), przy Rzeczniku Finansowym (dalej RF) - a więc podmiocie, który w praktyce stosuje pozasądowe procedury rozwiązywania sporów w określonych kategoriach spraw. Przedmiotowe badanie pozwala również na realizację zasadniczego celu artykułu, jakim jest weryfikacja stanowiska mediatorów (na przykładzie opinii mediatorów zatrudnionych w Biurze Rzecznika Finansowego) w kwestii potrzeby funkcjonowania wyspecjalizowanych centrów mediacji w Polsce.

\section{Funkcjonowanie wyspecjalizowanych centrów mediacji}

Tworzenie ośrodków mediacyjnych w Polsce przez organizacje społeczne i zawodowe, które świadczą usługi w zakresie pozasądowych metod rozwiązywania sporów, w tym prowadza postępowania w ramach tzw. mediacji instytucjonalnej ${ }^{16}$, zostało usankcjonowane przepisem art. $183^{2} \S 3$

14. Zob. m.in.: Polskie Centrum Mediacji, https://mediator.org.pl [dostęp: 26.02.2021]; Centrum Mediacji Lewiatan, http://konfederacjalewiatan.pl/mediacje [dostęp: 26.02.2021]; Centrum Mediacji przy Krajowej Izbie Radców Prawnych, http://mediacje.kirp.pl [dostęp: 26.01.20201]; Centrum Mediacji przy Naczelnej Radzie Adwokackiej; czy Centra Arbitrażu i Mediacji (CAM) powstałe w związku z realizacją projektów prowadzonych przez Ministerstwo Gospodarki, a następnie Ministerstwo Sprawiedliwości, https://www.cammediacje.pl/centra-arbitrazu-i-mediacji/czym-sa-centra-arbitrazui-mediacji-cam [dostęp: 26.02.2021]. Szerzej nt. CAM zob. np.: M. J. Skrodzka, A. Szafranek, M. Ziemblicki, Mediacja w sporach na rynkach finansowych na przykładzie Centrum Mediacji Sqdu Polubownego przy Komisji Nadzoru Finansowego, „Wiadomości Ubezpieczeniowe” 2021, nr 2.

15. Wyjątkami są Centrum Mediacji przy Krajowej Izbie Radców Prawnych, które prowadzi mediacje w sprawach gospodarczych, oraz wspomniane w poprzednim przypisie Centra Arbitrażu i Mediacji (CAM). Należy przy tym wskazać, że pomimo iż domeną CAM są zasadniczo postępowania mediacyjne w sprawach gospodarczych, to z doświadczenia (płynącego z kilkuletniej współpracy z CAM - Podlaskim Centrum Arbitrażu i Mediacji przy Izbie Przemysłowo-Handlowej w Białymstoku] wynika, że CAM prowadzą postępowania mediacyjne także w innych kategoriach, w tym m.in. w: sprawach cywilnych, rodzinnych czy z zakresu prawa pracy. Stąd nie moga być uznane za wyspecjalizowane centra mediacyjne.

16. Mediacja instytucjonalna funkcjonuje obok tzw. mediacji ad hoc, przez którą rozumie się postępowanie prowadzone przez mediatora wyznaczonego do określonej, pojedynczej sprawy (szerzej na ten temat zob. m.in.: M. Pazdan, 0 mediacji i projekcie jej unormowania w Polsce, „Rejent” 2004, nr r, s. 16; G. Frączek, Funkcjonowanie ośrodków mediacyjnych, „Kwartalnik ADR” 2011, nr 2(14), s. 25-27). 
k.p.c. ${ }^{17}$ Ich funkcjonowanie zaś odbywa się w oparciu o wewnętrzne akty - statuty czy regulaminy. Wskazany przepis odnosi się do organizacji pozarządowych, a więc podmiotów o charakterze prywatnym oraz uczelni. Z pewnością drugą możliwość zakładania wskazanych ośrodków, zwłaszcza w odniesieniu do tworzenia (także przez organy publiczne) i funkcjonowania wyspecjalizowanych centrów mediacyjnych, przewiduje ustawa o pozasądowym rozwiązywaniu sporów konsumenckich, która weszła w życie 10 stycznia 2017 roku $^{18}$. Ustawa implementowała do polskiego porządku prawnego dyrektywę Parlamentu Europejskiego i Rady 2013/11/UE z 21 maja 2013 roku w sprawie alternatywnych metod rozstrzygania sporów konsumenckich oraz zmiany rozporządzenia (WE) nr 2006/2004 i dyrektywy 2009/22/WE ${ }^{19}$, zwana potocznie dyrektywą ADR. Jej celem było stworzenie we wszystkich państwach członkowskich jednolitego systemu pozasądowego rozstrzygania sporów pomiędzy konsumentem a przedsiębiorcą. Przepisy u.p.r.s.k. przewiduja prowadzenie pozasądowych postępowań polegających na:

1) umożliwieniu zbliżenia stanowisk stron w celu rozwiązania sporu przez jego strony (np. w ramach mediacji),

2) przedstawieniu stronom propozycji rozwiązania sporu ( $\mathrm{np}$. w ramach koncyliacji, czy też postępowania mieszanego - łączącego elementy mediacji i koncyliacji),

3) rozstrzygnięciu sporu i narzuceniu stronom jego rozwiązania ( $\mathrm{np}$. w ramach postępowania arbitrażowego].

Postępowania te mają na celu rozwiązanie sporów konsumenckich ${ }^{20}$ przez podmioty uprawnione, spełniające wymagania określone w przepisach ustawy i wpisane do rejestru ${ }^{21}$.

Wprowadzenie przepisów u.p.r.s.k. pozwoliło na stworzenie, a w zasadzie uzupełnienie, systemu pozasądowego rozwiązywania sporów o wyspecjalizowane ośrodki mediacyjne - podmioty publiczne i organizacje przedsiębiorców utworzone na stałe i świadczące usługi w tym zakresie dla określonej grupy podmiotów (konsument - przedsiębiorca) oraz w określonych kategoriach spraw, w ramach niezależnych, bezstronnych i przejrzystych postępowań. W związku z tym powstały 22 publiczne i niepubliczne podmioty sektorowe świadczące usługi w ramach pozasądowego rozwiązywania sporów w branżach: finansowej, telekomunikacyjnej i pocztowej, energetycznej, transportowej oraz tzw. podmiot horyzontalny - Izba Handlowa - prowadzacy przedmiotowe postępowania w pozostałych branżach, w których nie powstały wyspecjalizowane podmioty ${ }^{23}$.

17. Ustawa z 17 listopada 1964 r. - Kodeks postępowania cywilnego [tekst jedn. Dz. U. 2020, poz. 1575 z późn. zm. J, dalej: k.p.c. Zgodnie z przepisem art. $183^{2} \S 3$ k.p.c. organizacje pozarządowe w zakresie swoich zadań statutowych oraz uczelnie mogą tworzyć ośrodki mediacyjne.

18. Ustawa z 23 września 2016 r. o pozasądowym rozwiązywaniu sporów konsumenckich (Dz. U. 2016, poz. 1823 z późn. zm.) dalej: u.p.r.s.k.

19. Dz.Urz. UE z 2013 r. L 165, s. 63.

20. Zgodnie z przepisem art. 2 pkt 3) u.p.r.s.k. sporem konsumenckim jest spór pomiędzy konsumentem a przedsiębiorcą wynikający z zawartej z konsumentem umowy.

21. Zgodnie z przepisem art. 20 i 30 u.p.r.s.k. rejestr podmiotów uprawnionych to wykaz instytucji, które zajmuja się pozasądowym rozwiązywaniem sporów konsumenckich. Jest on monitorowany przez Urząd Ochrony Konkurencji i Konsumentów.

22. W przypadku Sądu Polubownego Komisji Nadzoru Finansowego, który istniał przed wejściem w życie przepisów u.p.r.s.k., podmiotowi temu rozszerzono kompetencje o możliwość prowadzenia pozasądowych postępowań mających na celu rozwiązanie sporu o postępowania polubowne prowadzone w oparciu o przepis przedmiotowej ustaw.

23. Szerzej na ten temat zobacz: http://polubowne.uokik.gov.pl [dostęp: 26.02.2021]. 
Jednym (obok Sąu Polubownego przy Komisji Nadzoru Finansowego) z wyspecjalizowanych podmiotów prowadzących postępowania polubowne w oparciu o przepisy u.p.r.s.k. i przepisy szczególne ${ }^{24}$ w zakresie sporów na rynku usług finansowych jest Wydział Pozasądowego Rozwiązywania Sporów w Biurze Rzecznika Finansowego. Przedmiotowe postępowania charakteryzują się, podobnie jak mediacje prowadzone w oparciu o przepisy k.p.c., dobrowolnością (dla klienta), poufnością, odformalizowaniem i elastycznością oraz utrzymaniem kontroli przez strony przejawiającym się w możliwości składania przez nie wzajemnych propozycji w zakresie rozwiązania sporu.

Mediatorzy WRS prowadza postępowania mediacyjne / quasi-mediacyjne w zależności od wyboru trybu postępowania, którego dokonuje klient podmiotu rynku finansowego, składając wniosek o wszczęcie procedury. Osoba taka może wnosić o:

a) podjęcie czynności zmierzających do zbliżenia stanowisk stron (mediacja),

b) lub przedstawienie stronom propozycji rozwiązania sporu (koncyliacja),

c) lub połączenie obu tych procedur w jednym postępowaniu (procedura mieszana - mediacyjno-koncyliacyjna).

Jak wskazuje Rzecznik Finansowy, w ramach pierwszego sposobu działania mediatorzy WRS podejmują działania quasi-mediacyjne. Ich celem pomoc stronom w osiagnięciu porozumienia, poprzez przedstawienie stronom stanowisk, wyjaśnienie ich, czy organizację spotkań ${ }^{25}$. W przypadku wyboru drugiego trybu (koncyliacja), mediator WRS przedstawia stronom propozycję rozwiązania i zakończenia sporu, jeżeli w danej sprawie zaproponowanie rozwiązania jest możliwe ${ }^{26}$.

Po zakończeniu postępowania sporządzany jest protokół (doręczany stronom), a w przypadku braku zawartej ugody czy wypracowania innego porozumienia do protokołu dołączana jest opinia.

Możliwym potwierdzeniem wskazanych we wstępie prawidłowości, tj. potrzeby specjalizacji w zakresie profilowania obszaru mediacji, jest opisana ogólnie działalność WRS, który prowadzi ściśle określone postępowania mediacyjne / quasi-mediacyjne w zakresie sporów na rynku usług finansowych. Jest przy tym jednym z dwóch takich podmiotów (obok Sadu Polubownego przy Komisji Nadzoru Finansowego]. Dlatego prowadzone przez niego działania warto poddać szczegółowej analizie.

\section{Działalność WRS w Biurze Rzecznika Finansowego}

Prowadzone przez Wydział postępowania nie tylko zyskują na popularności (o czym poniżej), ale są również dobrze oceniane przez instytucje nadzorujace. Jak wynika z raportów Najwyższej Izby Kontroli (dalej: NIK), w latach 2016-2020 działania RF na rzecz ochrony klientów kredytów walutowych oraz produktów ubezpieczeniowych zostały ocenione jednoznacznie pozytywnie ${ }^{2 ?}$.

24. Ustawa 5 sierpnia 2015 r. o rozpatrywaniu reklamacji przez podmioty rynku finansowego oraz o Rzeczniku Finansowym (Dz. U. 2016, poz. 892 z późn. zm.); Rozporządzenie Ministra Rozwoju i Finansów z 15 lutego 2017 r. w sprawie pozasądowego postępowania przed Rzecznikiem Finansowym (Dz. U. 2017, poz. 313).

25. Więcej informacji na temat procedury, poza przepisami ustawy i rozporządzenia (zob. przypis 25), zob.: https://polubowne.rf.gov.pl/\#najczestsze-pytania [dostęp: 26.02.2021].

26. Ibidem.

27. Zob. Raport NIK, Ochrona praw konsumentów korzystajacych z kredytów objętych ryzykiem walutowym, Warszawa 2018, s. 89 i nast., https://www.nik.gov.pl/plik/id,17566,vp,20139.pdf [dostęp: 26.02.2021]; Raport NIK, Ochrona konsumentów na rynku ubezpieczeniowym, Warszawa 2019, s. 33-35 i 51-54, https://www. 
NIK jednocześnie podkreślał, że ograniczone uprawnienia Rzecznika hamują skuteczność podejmowanych przez niego interwencji.

Prowadzone przez Rzecznika statystyki (w sposób szczególny porównanie okresu 1.09.201831.08.2019 z okresem 1.09.2019-21.08.2020] wyraźnie wskazują na silny wzrost zainteresowania świadczonymi przez niego usługami, a także duży przyrost naruszeń prawa w sektorze bankowo-kapitałowym przez podmioty rynku finansowego ${ }^{28}$. Postępowanie polubowne prowadzone przed Rzecznikiem Finansowym cieszyło się i w dalszym ciagu cieszy się bardzo dużym zainteresowaniem (wyk. 1.).

Wykres 1. Liczba wniosków wpływających do Wydziału Pozasądowego Rozwiązywania Sporów

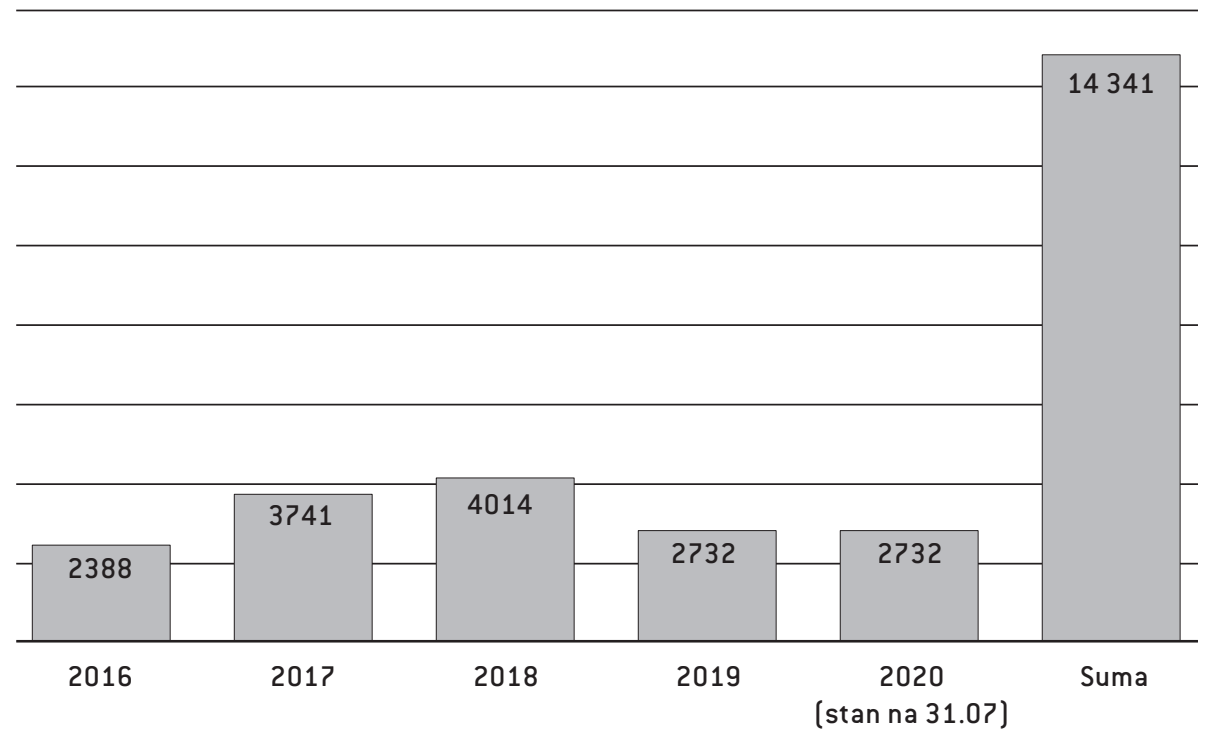

Źródło: Biała Księga Rzecznika Finansowego, Warszawa, październik 2020, s. 26.

Wprawdzie po systematycznym wzroście liczby wniosków (w okresie 2016-2018) w 2019 roku nastapił relatywnie duży spadek ${ }^{29}$, to jednak statystyki publikowane przez RF (stan na: 31.07.2020) wskazywały, że liczba wniosków, które wpłynęły do RF jedynie do końca lipca 2020 roku, była taka sama jak liczba wniosków z całego 2019 roku. Tym samym zaprezentowane dane stanowia potwierdzenie wzrostu zainteresowania polubownym rozwiązywaniem sporów prowadzonym przed RF.

nik.gov.pl/plik/id,21513,vp,24159.pdf [dostęp: 26.02.2021]. Zob. też: https://www.nik.gov.pl/aktualnosci/ kredyty-frankowe-panstwo-pozwolilo-bankom-na-zbyt-wiele.html [dostęp: 26.02.2021].

28. Biała Księga Rzecznika Finansowego, Warszawa, październik 2020, s. 5-6.

29. Jedną z przyczyn spadku liczby wniosków, kierowanych po roku 2018 do WRS, może być fakt, że klienci podmiotów rynku finansowego, którzy zawarli umowy o kredyty walutowe w latach 2006-2008, zdołali złożyć wnioski o wszczęcie postępowań w ramach procedury polubownego rozwiązania sporu do roku 2018, tj. zasadniczo do roku, w którym mogło dojść do przedawnienia roszczeń wynikających z zawieranych przez nich umów kredytowych. 
Tabela 1. Liczba spraw zakończonych w poszczególnych latach oraz liczba spraw, w których doszło do porozumienia / wydano opinię

\begin{tabular}{|l|c|c|c|c|c|c|}
\hline \multicolumn{1}{|c|}{ Rok } & 2016 & 2017 & 2018 & 2019 & $\begin{array}{c}2020 \text { (stan } \\
\text { na: } 31.07)\end{array}$ & Razem \\
\hline Łączna liczba spraw zakończonych & 358 & 2007 & 2968 & 2997 & 2178 & 10508 \\
\hline $\begin{array}{l}\text { Liczba spraw zakończonych } \\
\text { porozumieniem }\end{array}$ & 124 & 424 & 388 & 369 & 208 & 1518 \\
\hline Liczba spraw zakończonych opinia & 56 & 931 & 1444 & 1837 & 1606 & 5874 \\
\hline
\end{tabular}

Źródło: Biała Księga Rzecznika Finansowego, Warszawa, październik 2020, s. 27.

Z przedłożonego przez RF w 2020 roku raportu ${ }^{30}$ wynika, że liczba zamkniętych spraw (tab. 1.) jest uznawana za istotne osiagnięcie, zważywszy na obowiązkowy udział w postępowaniu podmiotów rynku finansowego. Obligatoryjność udziału w postępowaniu, usankcjonowana w przepisach, wpływa nie tylko na jego trudniejszy charakter, zwiększona pracochłonność i / lub czasochłonność, ale także wrażenie jego niskiej efektywności (biorąc pod uwagę zestawienie ogólnej liczby spraw z tymi, które zakończyły się porozumieniem). Jednak zważywszy na wspomniana już konieczność udziału podmiotu rynku finansowego w przedmiotowym postępowaniu (która w wielu przypadkach nie idzie w parze z przekonaniem o możliwości polubownego rozwiązania sporu), wrażenie niskiej efektywności procedury na podstawie odsetka spraw zakończonych ugodą nie powinno być traktowane jako miarodajny wskaźnik. W związku z powyższym w przypadku praktyki Wydziału i obowiązujących regulacji prawnych (w sposób szczególny chodzi o przywołana już wcześniej obligatoryjność udziału w postępowaniach) niemożliwe jest zastosowanie prostych - sprawdzających się w przypadku innych podmiotów (np. KNF) wskaźników efektywności działania Wydziału tylko i wyłącznie w oparciu o liczbę zawartych ugód. Przy czym, jak wynika ze Sprawozdań z działalności WRS ${ }^{31}$, jednoznacznie wskazujących na zdecydowany wzrost odsetka spraw zakończonych ugodą ${ }^{32}$, także w praktyce Wydziału ów wskaźnik jest wysoki.

Dlatego też, z uwagi na ograniczoną liczbę podmiotów realizujących wyspecjalizowane obszarowo usługi mediacyjne, przywołane wyżej statystyki oraz przedstawione w tab. 1. rekordy potwierdzaja, że polubowne postępowanie prowadzone przed RF stanowi znaczny krajowy udział tego typu postępowań na rynku usług finansowych ${ }^{33}$. Co więcej, powołane dane powinny być traktowane w katego-

30. Ibidem, s. 27-28.

31. Sprawozdania z działalności Wydziału Pozasądowego Rozwiązywania Sporów w Biurze Rzecznika Finansowego za 2017 r., 2018 r., 2019 r.: https://rf.gov.pl/o-nas/sprawozdania/ [dostęp: 28.02.2021].

32. Dla przykładu w roku 2017 był to wzrost o $241 \%$ w stosunku do roku 2016.

33. Dla porównania: ze sprawozdania z działalności za rok 2018 Sądu Polubownego przy Komisji Nadzoru Finansowego wynika, że w 2018 r. do Sądu Polubownego wpłynęło ponad 2314 wniosków o przeprowadzenie mediacji, złożonych zarówno przez instytucje finansowe, jak i ich klientów, a postępowanie mediacyjne udało się przeprowadzić w ok. 44\% z nich - tj. 1044 sprawach, z czego w ponad 80\% udało się zawrzeć ugodę (zob. Sprawozdanie z działalności Sądu Polubownego Przy Komisji Nadzoru Finansowego w 2018 r.: https:// www.knf.gov.pl/knf/pl/komponenty/img/sprawozdanie_z_dzialalnosci_sadu_polubownego_za_2018_65357.pdf [dostęp: 28.02.2021]]. Ponadto w 2019 r. do Sądu Polubownego wpłynęło łącznie 2724 wniosków o przeprowadzenie postępowania mediacyjnego, z czego w 1569 spraw wszczęto przedmiotowe postępowanie, a 42 sprawy zakończono pozytywnie przed formalnym rozpoczęciem mediacji (zob.: Sprawozdanie z działalności Urzędu Komisji Nadzoru Finansowego oraz Komisji Nadzoru Finansowego w 2019 r., s. 177-178, na: https:// www.knf.gov.pl/knf/pl/komponenty/img/Sprawozdanie\%202019.pdf [dostęp: 28.02.2021]]. 
rii czynnika potwierdzającego efektywność prowadzonych w Wydziale postępowań. Za poparciem powyższego stanowiska przemawia także fakt, że w latach 2017-202034 , dzięki działalności RF uzyskano porozumienia na kwotę 11,8 mln zł, co nie tylko wskazuje na skuteczność działań prowadzonych w Wydziale, ale jest także potwierdzeniem zasadności jego istnienia i potrzeby rozwoju.

\section{Ocena roli wyspecjalizowanego centrum mediacji - perspektywa mediatorów}

W celu oceny roli wyspecjalizowanych centrów mediacji, co wskazano na początku opracowania, zrealizowano sondaż diagnostyczny wśród mediatorów zatrudnionych w WRS ${ }^{35}$. W badaniach wzięło udział siedmioro mediatorów (z 13 zatrudnionych), jednak z uwagi na duże braki formalne jeden kwestionariusz został odrzucony. Ostatecznie w analizie uwzględniono odpowiedzi udzielone przez sześcioro mediatorów (co stanowi 46,2\% spośród wszystkich zatrudnionych w instytucji). Mimo że nie udało się przekonać wszystkich pracowników Wydziału do wzięcia udziału w badaniach, to jednak liczba uzyskanych wyników może być uznana za zadowalająca, bowiem są to praktycy mający duże doświadczenie mediacyjne i jednocześnie wiedzę w zakresie podejmowanej problematyki.

W badaniach wzięły udział trzy kobiety oraz trzech mężczyzn, przy czym tylko jeden respondent wskazał, że staż pracy jako mediator w WSR jest krótszy niż rok. Pozostałe osoby pracują w instytucji co najmniej rok, co wiąże się z przeprowadzeniem ponad 200 postępowań rocznie. Taki wynik wskazuje na posiadanie dużego doświadczenia mediacyjnego badanych i praktyczne spostrzeżenia z perspektywy analizowanej tematyki (na co zwracano uwagę już wcześniej). Tylko jedna osoba (o najkrótszym stażu) prowadziła 80 spraw, zaś pozostali badani wskazali od 350 do nawet 1000 spraw, przy czym czworo z nich zrealizowało powyżej 700 postępowań. Należy jednocześnie odnotować, że część spraw umorzono ze względu na wycofanie wniosku przez klienta w trakcie postępowania lub w związku z niemożnością jego kontynuowania, np. z powodu wstapienia przez strony na drogę sądową ${ }^{36}$ (zgodnie z odpowiedziami badanych liczba umorzonych spraw mieści się w przedziale 5-50). Respondenci wskazali, że prowadzili zarówno postępowania sądowe, jak i pozasądowe (odpowiednio po 3 wskazania). Przy czym rozbieżność w liczbie tych postępowań jest duża i wynosi odpowiednio: 10, 100 i 150 (w przypadku postępowań sądowych) oraz 10, 50, 75 (w przypadku postępowań pozasądowych). Należy wskazać, że wszyscy badani legitymują się wykształceniem wyższym prawniczym, przy czym 3 z nich prowadzi własna praktykę jako radca prawny / adwokat (nadmienić jednocześnie należy, że praktyka jest prowadzona co najmniej 3 lata - jedna osoba, bądź powyżej 5 lat - dwie osoby). Połowa z nich ma także doświadczenie mediacyjne poza WRS jako mediator sądowy / pozasądowy, trwające: poniżej roku (w przypadku 1 osoby), powyżej 8 lat ( 3 wskazania).

W kontekście liczby postępowań istotne są także liczba zawieranych ugód oraz obszary, w jakich prowadzone sa mediacje. W zakresie polubownego sposobu zakończenia sporu badani dokonywali oceny, wskazując liczbę (3, 20, kilkadziesiąt, bądź 110) bądź odsetek (20\%, 12-15\%) ugód. Przy czym obszar prowadzonych spraw jest dość szeroki (tab. 2.).

34. Dane uwzględniające wyłącznie z pierwsze półrocze roku 2020.

35. Badanie zrealizowano na przełomie grudnia 2020 roku oraz stycznia 2021 roku, za pomocą techniki ankiety, przy wykorzystaniu narzędzia badawczego w postaci kwestionariusza ankiety.

36. Zob. §15 Rozporządzenia Ministra Rozwoju i Finansów z 15 lutego 2017 r. w sprawie pozasądowego... 
Tabela 2. Obszar spraw prowadzonych w WRS

\begin{tabular}{|l|c|}
\hline \multicolumn{1}{|c|}{ Obszary } & N \\
\hline $\begin{array}{l}\text { Sprawy bankowe (w tym: kredyty frankowe, nienależnie pobrane środki z kart płatniczych, } \\
\text { wydawanie kart płatniczych) }\end{array}$ & 5 \\
\hline Sprawy ubezpieczeniowe (ubezpieczenia majątkowe, osobowe i na życie) & 4 \\
\hline Sprawy majątkowe & 1 \\
\hline
\end{tabular}

* Liczba $\mathrm{N}$ nie równa się 6 , bowiem respondenci wskazywali kilka odpowiedzi.

Niemal wszystkim badanym zdarzało się prowadzić sprawy ubezpieczeniowe, jak również sprawy bankowe, które w większości dotyczyły kredytów frankowych.

Już na wstępie analizy należy zaznaczyć, że wszyscy mediatorzy bioracy udział w badaniu uznaja przydatność i jednocześnie zasadność prowadzenia postępowań w sprawie rozwiązywania sporów przez Rzecznika Finansowego. Badani oceniali także przewagę pozasądowych postępowań w zakresie rozwiązywania sporów prowadzonych przez Rzecznika Finansowego nad typowa mediacją sądową / pozasądową (tab. 3.).

Tabela 3. Uzasadnienie przewagi pozasądowych postępowań w sprawie rozwiązywania sporów prowadzonych przez Rzecznika Finansowego

\begin{tabular}{|l|c|}
\hline \multicolumn{1}{|c|}{ Przykład uzasadnienia } & N \\
\hline Autorytet Rzecznika Finansowego & 3 \\
\hline „Przymusowa dobrowolność” - obowiązek udziału podmiotu rynku finansowego w postępowaniu & 2 \\
\hline Duże doświadczenie i wiedza prawna pracowników Rzecznika Finansowego & 2 \\
\hline Profesjonalne podejście do stron (w tym także w zakresie oceny ryzyka) & 1 \\
\hline Większe możliwości Rzecznika Finansowego w zakresie koncyliacji & 1 \\
\hline
\end{tabular}

* Liczba $\mathrm{N}$ nie równa się 6 , bowiem respondenci wskazywali kilka odpowiedzi.

Uzyskane odpowiedzi wyraźnie wykazały wagę autorytetu w przypadku prowadzenia postępowań mediacyjnych. Zatrudnieni w WRS badani (którzy prowadzą także praktykę mediacyjna poza WRS] podkreślali duże znaczenie autorytetu samej instytucji, jak również osoby nią kierujacej. W praktyce przekłada się to na profesjonalizm (analizowany dwojako) w zakresie: podejścia mediatorów do stron postępowania, jak również poważnego podejścia stron do samej instytucji mediacji. Wskazane zachowania maja z kolei niebagatelny wpływ na powodzenie procedury mediacyjnej. Ponadto, na korzyść postępowań prowadzonych przed Rzecznikiem działa tzw. „przymusowa dobrowolność" - polegająca na obowiązku udziału podmiotów rynku finansowego w postępowaniu mediacyjnym. Respondenci wskazywali również, że pracownicy WRS cechują się nie tylko wiedza prawna, profesjonalnym podejściem do stron, ale także dużym doświadczeniem mediacyjnym (potwierdzonym liczbą zrealizowanych mediacji oraz, w większości przypadków, kilkuletnią praktyka).

Kolejnym argumentem dowodzącym przewagi postępowań prowadzonych przed Rzecznikiem Finansowym nad postępowaniami prowadzonymi przez ogólne ośrodki mediacyjne jest możliwość połączenia elementów procedur stosowanych w postępowaniach mediacyjnych z elementami procedur stosowanych w zakresie postępowań koncyliacyjnych. Wszyscy badani zadeklarowali, 
że jest to dobre rozwiązanie, uznając całkowitą zasadność (4 wskazania), badź częściową zasadność (2 wskazania) takiej praktyki. Swoją opinię respondenci motywowali przede wszystkim możliwością złożenia stronom propozycji rozwiązania sporu, co w wielu sytuacjach stanowi bardzo dobre rozwiązanie, zaś w przypadku zastosowania „tradycyjnego” podejścia mediacyjnego, takie działanie nie mogłoby mieć miejsca.

Badani dokonali także oceny przydatności pozasądowych postępowań w sprawie rozwiązywania sporów prowadzonych przez Rzecznika, uwzględniając różne punkty widzenia, tj. perspektywę klientów korzystających z usług podmiotów rynku finansowego, samych podmiotów rynku finansowego, jak również mediatorów (tab. 4.].

Tabela 4. Ocena przydatności postępowań w sprawie rozwiązywania sporów w zależności od podmiotu

\begin{tabular}{|l|c|c|c|}
\hline & Perspektywa klientów & $\begin{array}{c}\text { Perspektywa podmiotów } \\
\text { rynku finansowego }\end{array}$ & Perspektywa mediatorów \\
\hline W bardzo dużym stopniu & 2 & 1 & 3 \\
\hline W dużym stopniu & 4 & 3 & 3 \\
\hline W małym stopniu & 0 & 1 & 0 \\
\hline W bardzo małym stopniu & 0 & 1 & 0 \\
\hline
\end{tabular}

W ich opinii postępowania w sprawie rozwiazywania sporów, prowadzone w WRS, są przydatne przede wszystkim z perspektywy klientów podmiotów rynku finansowego, jak również mediatorów. Nieco mniej korzystnie przydatność oceniono z punktu widzenia podmiotów rynku finansowego. Respondenci sugerowali, że w wielu przypadkach konsument składający reklamację nie jest przez „podmiot” traktowany z należyta powaga. Jednak w sytuacji, kiedy postępowanie jest wszczynane i prowadzone przez Rzecznika Finansowego, zwykle sposób traktowania klienta zmienia się na jego korzyść. Taka prawidłowość stanowi jedno z uzasadnień większej oceny przydatności tego typu postępowań z perspektywy klienta niż z perspektywy podmiotów rynku finansowego (tab. 5.).

Tabela 5. Uzasadnienia oceny przydatności prowadzenia sporów przed Rzecznikiem Finansowym

\begin{tabular}{|l|c|}
\hline \multicolumn{1}{|c|}{ Przykład uzasadnienia } & N \\
\hline Silna pozycja i autorytet Rzecznika Finansowego & 2 \\
\hline $\begin{array}{l}\text { Profesjonalna wiedza mediatorów i umiejętność komunikacji zarówno z konsumentem, jak } \\
\text { i podmiotem finansowym }\end{array}$ & 3 \\
\hline Inny (lepszy, bardziej poważny) sposób traktowania klienta & 3 \\
\hline Możliwość pozasądowego rozwiązania sporu (krótszy czas trwania i niższe koszty) & 3 \\
\hline Obrona interesu konsumenta & 2 \\
\hline
\end{tabular}

* Liczba $\mathrm{N}$ nie równa się 6 , bowiem respondenci wskazywali kilka odpowiedzi.

Wypowiedzi badanych prowadzą do wniosku, że podmioty rynku finansowego są dominujacą (silniejsza) stroną sporu w porównaniu ze „zwykłym” konsumentem. Mimo że udział mediatora cechuje bezstronność, to jednak dysponuje on stosownymi narzędziami mającymi na celu wzmocnienie słabszej strony (klienta) postępowania mediacyjnego. Postępowanie prowadzone przed Rzecznikiem zwiększa równowagę stron i pozwala im na uczestnictwo w profesjonalnym 
postępowaniu przy udziale mediatora posiadającego wiedzę i umiejętności komunikacji zarówno z indywidualnym klientem, jak i z podmiotem rynku finansowego.

Badani mieli także wskazać wady i zalety postępowań prowadzonych przed Rzecznikiem. Warto zaznaczyć, że wady takich postępowań dostrzegła jedynie połowa badanych ( 3 osoby). Jako najistotniejszą wadę (wskazana przez 3 respondentów) uznano zbyt długi czas trwania postępowania. Drugą istotną wadą jest silne zbiurokratyzowanie procedury - szczególnie jej części wstępnej, także w zakresie wydawania opinii, która powinna być według badanych fakultatywna, a jest obligatoryjna. Jeden z badanych podkreślił jednocześnie, że do WRS wpływa zbyt duża liczba wniosków, nieadekwatna do liczby zatrudnionych w nim osób - braki kadrowe uniemożliwiają sprawną realizację wszystkich postępowań (w tym także przygotowanie ich pod względem formalnym).

Za zalety postępowań prowadzonych w WRS uznano przede wszystkim „realna pomoc niektórym konsumentom, którzy wcześniej nie zostali wysłuchani przez podmiot”, możliwość uzyskania profesjonalnej pomocy, jak również „dobre relacje z podmiotami rynku finansowego” przy jednoczesnym „zaufaniu klientów podmiotów rynku finansowego” oraz „wnikliwą, obiektywna ocenę stanu faktycznego sprawy w opinii kończącej postępowanie w przypadku braku osiagnięcia porozumienia między stronami".

Należy nadmienić, że wszyscy badani uznali, że prowadzone przed Rzecznikiem postępowania zasługują na miano efektywnych. Za główne wskaźniki poziomu efektywności uznano: liczbę zawieranych porozumień (4 wskazania), liczbę spraw kierowanych do pozasądowych postępowań w sprawie rozwiązywania sporów (1 wskazanie) oraz możliwość poważnego potraktowania konsumenta przez podmiot rynku finansowego (1 wskazanie).

Jednocześnie wszyscy respondenci uznali, że należy podjąć działania mające na celu zwiększenie efektywności postępowań toczących się przed Rzecznikiem Finansowym (tab. 6.).

Tabela 6. Sposoby zwiększenia efektywności postępowań prowadzonych przed Rzecznikiem Finansowym

\begin{tabular}{|l|c|}
\hline \multicolumn{1}{|c|}{ Przykład sposobu zwiększenia efektywności postępowania } & N \\
\hline Odformalizowanie postępowania (szczególnie jego pierwszej części) & 3 \\
\hline $\begin{array}{l}\text { Wprowadzenia zmian w zakresie opiniowania (np. opinia na wniosek bądź całkowita rezygnacja } \\
\text { z opiniowania) }\end{array}$ & 3 \\
\hline $\begin{array}{l}\text { Zmiana organizacji wydziału (np. częstsze spotkanie mediatorów celem wymiany doświadczeń, } \\
\text { wprowadzenie kryteriów kierowania spraw do poszczególnych mediatorów, kontrolowanie liczby } \\
\text { spraw przydzielanych mediatorom, zwiększenie liczby pracowników WRS) }\end{array}$ & 3 \\
\hline $\begin{array}{l}\text { Zwiększenie kompetencji Rzecznika przez możliwość nakładania kar na podmioty rynku } \\
\text { finansowego, które biora udział w postępowaniu jedynie „dla zasady” }\end{array}$ & 1 \\
\hline
\end{tabular}

* Liczba $\mathrm{N}$ nie równa się 6 , bowiem respondenci wskazywali kilka odpowiedzi.

Badani widzą dużą potrzebę zmian w sposobie opiniowania. Część z nich uważa za zasadne wprowadzenie „opinii na wniosek”, przy czym pojawiły się także postulaty całkowitej rezygnacji z opinii. Uzasadniając swoje przekonania, respondenci wskazywali, że sporządzenie opinii musi być poprzedzone skrupulatna analizą nie tylko stanu faktycznego danej sprawy, ale także orzecznictwa, co stanowi zbyt czasochłonne zadanie. Powyższa motywacja dotyczy także postulatu „odformalizowania postępowania", które w obecnym kształcie generuje procedurę trwająca zbyt długo. Badani podkreślali również, że bardzo ważnym postulatem jest wprowadzenie zmiany w zakresie organizacji Wydziału. Ta powinna polegać na zwiększeniu liczby pracowników WRS i kontrolowaniu 
liczby przydzielanych im spraw. Wskazane modyfikacje przełożyłyby się na krótszy czas oczekiwania stron na przeprowadzenie postępowania, jak również zwiększyłyby efektywność pracy mediatorów, mających obecnie zbyt dużą liczbę spraw jednocześnie. Ponadto organizacja wydziału powinna ulec zmianie w zakresie wprowadzenia możliwości konsultowania spraw z niezależnymi ekspertami, jak również zwiększenia częstotliwości spotkań pracowników, które miałyby na celu wymianę doświadczeń i możliwość dyskusji.

Poza ocena postępowania respondenci dokonali także oceny WRS. Opinie na temat struktury organizacyjnej Wydziału w zakresie sprawnego prowadzenia postępowań pozasądowych były podzielone. Połowa badanych ( 3 osoby) wskazała, że obecna struktura organizacyjna WRS pozwala na sprawną realizację zadań, zaś druga połowa była przeciwnego zdania. Już w ocenie sposobów zwiększenia efektywności postępowań zwracano uwagę na potrzebę reorganizacji struktury wydziału i sposobów komunikacji, m.in. w zakresie zwiększenia liczby mediatorów i opracowania systemu przydzielania spraw, obecnie stosowany jest bowiem, jak wskazał jeden z respondentów: „zróżnicowany tematycznie i zakresem spraw przydział do mediatora (brak specjalizacji) - na 20 przydzielanych mediatorowi spraw w zasadzie każda jest z innej działki”, co wpływa na zbyt długi czas trwania formalnej analizy wniosku. Zwrócono po raz kolejny uwagę na wysoce sformalizowane sposoby pracy, np. „konieczność odpisywania przez mediatora na skargi i pisma klientów po zakończeniu postępowania" oraz trudności w zakresie komunikacji, zarówno między pracownikami, jak i stronami (np. „brak jasnej, czytelnej i zrozumiałej dla klienta informacji nt. zasad pozasądowego postępowania i czasu trwania postępowania"). Większość badanych (4 osoby) wskazała jednocześnie, że liczba pracowników Wydziału jest zbyt mała, a co za tym idzie - nieadekwatna do liczby realizowanych postępowań. Jednakże wszyscy respondenci potwierdzili, że istnienie Wydziału Pozasądowego Rozwiązywania Sporów przy Rzeczniku Finansowym jest w pełni zasadne.

Badani jednoznacznie pozytywnie ocenili swoją rolę (jako mediatora) w pozasądowych postępowaniach realizowanych przed Rzecznikiem Finansowym (tab. ?.).

Tabela ?. Rola mediatora w pozasądowych postępowaniach realizowanych przed Rzecznikiem Finansowym

\begin{tabular}{|l|c|}
\hline \multicolumn{1}{|c|}{ Rola mediatora } & N \\
\hline Bardzo ważna (kluczowa) & 2 \\
\hline Wyjaśnienie istoty problemu (konfliktu), pozycji mediatora w sporze & 3 \\
\hline Umożliwienie komunikacji pomiędzy stronami & 3 \\
\hline
\end{tabular}

* Liczba $\mathrm{N}$ nie równa się 6 , bowiem respondenci wskazywali kilka odpowiedzi.

Ponadto zwrócono uwagę na rolę mediatora w zakresie wsparcia (usprawnienia) komunikacji między stronami ( 3 wskazania), jak również pomocy w wyjaśnieniu istoty konfliktu i / lub pozycji stron w sporze ( 3 wskazania). Kluczowa rola mediatora, w opinii badanych, polega przede wszystkim na „urealnieniu oczekiwań stron”, zrozumieniu problemu, co z kolei prowadzi do budowania relacji pomiędzy stronami. 


\section{Zakończenie}

Przedstawione w artykule dane statystyczne, jak również wyniki przeprowadzonych badań empirycznych (perspektywa praktyków), pozwoliły na realizację zasadniczego celu opracowania, tj. dokonanie oceny w zakresie potrzeby istnienia, funkcjonowania i określenia roli wyspecjalizowanych centrów mediacji, świadczących usługi w ściśle określonej kategorii spraw (specjalizacja przedmiotowa) w sposób jednoznacznie pozytywny. Na podstawie statystyk RF dotyczących liczby prowadzonych postępowań mediacyjnych (przedstawianych w corocznych raportach) oraz opinii zatrudnionych w Wydziale mediatorów (wskazujących na dużą liczbę spraw kierowanych do każdego z nich] można wnioskować o zasadności prowadzenia profesjonalnych instytucji o specjalizacji przedmiotowej, w pewnych szczególnych obszarach. Po pierwsze, taka specyfikacja jest korzystna z punktu widzenia mediatorów, którzy cechują się doświadczeniem i pogłębioną wiedzą w danym obszarze tematycznym. Po drugie - a może przede wszystkim - z punktu widzenia stron uzyskujących informacje na temat instytucji, do której powinny się zgłosić celem otrzymania profesjonalnej pomocy. Należy jednocześnie poddać pod rozwagę konieczność wypracowania miarodajnych wskaźników, uprawniających do analizy porównawczej skuteczności prowadzonych przez poszczególne podmioty postępowań mediacyjnych. Z uwagi bowiem na uregulowana prawnie obligatoryjność udziału podmiotów rynku finansowego w postępowaniach mediacyjnych ( co w wielu przypadkach nie jest równoznaczne z chęcią polubownego rozwiązania sporu) odsetek zawartych ugód, nie stanowi, w przekonaniu autorek, podstawy do wnioskowania o efektywności działań Wydziału i nie w pełni świadczy o jego efektywności (lub jej braku). Pomimo to - m.in. w związku z posiadanym doświadczeniem praktycznym w zakresie mediacji - autorki sa przekonane o potrzebie funkcjonowania i konieczności dalszego rozwoju wyspecjalizowanych centrów mediacji, działających w ramach systemu polubownego rozwiązywania sporów. Przykład WRS pokazuje bowiem, że w ramach wyspecjalizowanych centrów usługi w zakresie postępowań polubownych świadczą osoby posiadające odpowiednią wiedzę i dysponujące dużym doświadczeniem praktycznym (w zakresie stosowania prawa i / lub ADR), co przekłada się na realna pomoc osobom jej potrzebujacym, tym przypadku konsumentom (często reprezentującym samych siebie), a więc podmiotom słabszym w porównaniu z dużymi podmiotami rynku finansowego będącymi druga strona postępowania.

Autorki stoją na stanowisku, że istnienie wyspecjalizowanych centrów mediacji pozwala świadczyć usługi na bardzo wysokim poziomie, przy zachowaniu równie wysokiej skuteczności, pomimo np. sformalizowania postępowań w ramach procedur pozasądowego rozwiązania sporu czy braków kadrowych. Jest to spowodowane m.in. faktem stałego podnoszenia kompetencji przez pracujących tam mediatorów oraz poszerzania posiadanej wiedzy w zakresie szybko zmieniających się przepisów prawa i najnowszego orzecznictwa. Tak profesjonalne usługi świadczone przez wyspecjalizowane ośrodki mediacyjne są zaś - w dobie zachodzących przemian polityczno-społeczno-gospodarczych - wysoce pożądane. 


\section{Wykaz źródeł}

Araszkiewicz M., Płeszka K., Pojęcie alternatywnego rozwiqzywania sporów, [w: ] Mediacja. Normy, teoria, praktyka, Płeszka K., Czapska J., Araszkiewicz M., Pękala M. [red.], Wolters Kluwer, Warszawa 2017.

Bednarz K., Koncepcja sprawiedliwości naprawczej wg Leona Petrażyckiego a mediacja w procesie cywilnym, [w:] Prawo i nauka w pogladach Leona Petrażyckiego, Gil D., Pikuła Ł. [red.], Wydawnictwo KUL, Lublin 2013.

Biała Księga Rzecznika Finansowego, Warszawa 2020.

Centra Arbitrażu i Mediacji (CAM) powstałe w związku z realizacja projektów prowadzonych przez Ministerstwo Gospodarki, a następnie Ministerstwo Sprawiedliwości, https://www.cammediacje. $\mathrm{pl} /$ centra-arbitrazu-i-mediacji/czym-sa-centra-arbitrazui-mediacji-cam [dostęp: 26.02.2021]. Centrum Mediacji Lewiatan, http://konfederacjalewiatan.pl/mediacje [26.02.2021].

Centrum Mediacji przy Krajowej Izbie Radców Prawnych, http://mediacje.kirp.pl [dostęp: 26.01.2021]. Centrum Mediacji przy Naczelnej Radzie Adwokackiej, http://centrummediacji.nra.pl [dostęp: 26.02.2021].

Flejszar R., Gajda-Roszczynialska K., Alternatywne metody rozwiq̨ywania sporów ze szczególnym uwzględnieniem mediacji - postępowanie cywilne, [w:] Mediacja. Normy, teoria, praktyka, Płeszka K., Czapska J., Araszkiewicz M., Pękala M. [red.], Wolters Kluwer, Warszawa 201 ? Frączek G., Funkcjonowanie ośrodków mediacyjnych, „Kwartalnik ADR” 2011, nr 2/14.

Gmurzyńska E., Mediacja w sprawach cywilnych w amerykańskim systemie prawnym. Zastosowanie w Europie i w Polsce, CH Beck, Warszawa 200 ?.

Historia mediacji, https://www.lublin.so.gov.pl/historia-mediacji,m,mg,282,303 [dostęp: 26.02.2021]. Historia PCM, https://mediator.org.pl/o-nas/historia-pcm/ [dostęp: 26.02.2021].

Korybski A., Alternatywne rozwiqzywanie sporów w USA. Studium teoretycznoprawne, Wydawnictwo UMCS, Lublin 1993.

Masternak-Kubiak M., Komentarz do art. 175 Konstytucji RP, [w:] Konstytucja Rzeczypospolitej Polskiej. Komentarz, Haczkowska M. [red.], Lex online, 2019.

Ministerstwo Sprawiedliwości, https://www.gov.pl/web/sprawiedliwosc/dane-statystyczne-dotyczace-mediacji [dostęp: 26.02.2021].

Morek R., ADR - w sprawach gospodarczych, CH Beck, Warszawa 2004.

Najwyższa Izba Kontroli, https://www.nik.gov.pl/aktualnosci/kredyty-frankowe-panstwo-pozwolilo-bankom-na-zbyt-wiele.html [dostęp: 26.02.2021].

Pazdan M., 0 mediacji i projekcie jej unormowania w Polsce, „Rejent” 2004, nr 2.

Petrażycki L., O nauce, prawie i moralności. Pisma wybrane, PWN, Warszawa 1985.

Pieckowski S., Mediacja gospodarcza, Difin, Warszawa 2015.

Polskie Centrum Mediacji, https://mediator.org.pl [dostęp: 26.02.2021].

Raport NIK, Ochrona konsumentów na rynku ubezpieczeniowym, Warszawa 2019, https://www. nik.gov.pl/plik/id,21513,vp,24159.pdf [dostęp: 26.02.2021].

Raport NIK, Ochrona praw konsumentów korzystajacych z kredytów objętych ryzykiem walutowym, Warszawa 2018, https://www.nik.gov.pl/plik/id,17566,vp,20139.pdf [dostęp: 26.02.2021].

Skrodzka M.J., Zemke-Górecka A. Instytucja mediacji w polskim porzqdku prawnym - jej rozwój i przyszłość w sporach z zakresu prawa cywilnego, „Palestra” 2019, nr 11-12. 
Skrodzka M.J., Szafranek A., Ziemblicki M., Mediacja w sporach na rynkach finansowych na przykładzie Centrum Mediacji Sqdu Polubownego przy Komisji Nadzoru Finansowego, „Wiadomości Ubezpieczeniowe" 2021, nr 2.

Społeczna Rada do spraw Alternatywnych Metod Rozwiązywania Sporów, https://www.mediacja. gov.pl/Spo-eczna-Rada-do-spraw-Alternatywnych-Metod-Rozwi.html [dostęp: 26.02.2021].

Sprawozdania z działalności Wydziału Pozasądowego Rozwiązywania Sporów w Biurze Rzecznika

Finansowego za 2017 r., 2018 r., 2019 r., https://rf.gov.pl/o-nas/sprawozdania/ [dostęp: 28.02.2021].

Sprawozdanie z działalności Sądu Polubownego Przy Komisji Nadzoru Finansowego w 2018 roku, https://www.knf.gov.pl/knf/pl/komponenty/img/sprawozdanie_z_dzialalnosci_sadu_polubownego_za_2018_65357.pdf [dostęp: 28.02.2021].

Sprawozdanie z działalności Urzędu Komisji Nadzoru Finansowego oraz Komisji Nadzoru Finansowego

w 2019 roku, s. 177-178, dostępne na: https://www.knf.gov.pl/knf/pl/komponenty/img/ Sprawozdanie\%202019.pdf [dostęp: 28.02.2021].

Urząd Ochrony Konkurencji i Konsumentów, http://polubowne.uokik.gov.pl [dostęp: 26.02.2021]. Weitz K., Gajda-Roszczynialska K., Alternatywne metody rozwiqzywania sporów ze szczególnym uwzględnieniem mediacji, [w:] Mediacja w sprawach gospodarczych. Praktyka-teoria-perspektywy, Torbus A. [red.], Ministerstwo Gospodarki, Warszawa 2015.

Zienkiewicz A., Studium mediacji. Od teorii ku praktyce, Difin, Warszawa 2007.

Zienkiewicz Adam, Mediacja jako forma wymiaru sprawiedliwości, „Arbitraż i Mediacje 2013, nr 4.

\section{Assessment of the role of Specialized Mediation Centers on the example of the Out-of-Court Dispute Resolution Department in the Financial Ombudsman's Office}

The institution of mediation - one of the Alternative Dispute Resolution methods enjoys a steady increase in interest, both in law and in practice, which meant that at the beginning of the $21^{\text {st }}$ century various mediation centers specializing in out-of-court dispute resolution using the method began to appear in Poland.

In connection with the above, a question arises about the need for the existence, operation and role of specialized mediation centers - centers providing services in the framework of out-of-court dispute resolution in the form of mediation proceedings in a strictly defined category of cases (subject specialization]. A partial answer to this question is provided by the latest analysis of the study conducted by the authors of this article among mediators employed by the Out-of-Court Dispute Resolution Department at the Financial Ombudsman - an entity that in practice uses out-of-court dispute resolution procedures in specific categories of cases. The study also allows the implementation of the main objective of the article, which is to verify the position of mediators (based on the opinion of mediators employed in the Office of the Financial Ombudsman] regarding the need for specialized mediation centers in Poland.

Key words: $A D R$, mediation, out-of-court dispute resolution, amicable dispute resolution, Financial $\mathrm{Om}$ budsman, disputes on the financial market. 
DR MARTA J. SKRODZKA - Wydział Nauk Społecznych i Humanistycznych Państwowej Wyższej Szkoły Informatyki i Przedsiębiorczości w Łomży, Katedra Nauk Prawnych

ORCID: 0000-0001-5995-1394

e-mail:mjskrodzka@pwsip.edu.pl,skrodzkam@life.pl

DR ANNA SZAFRANEK - Wydział Nauk Społecznych i Humanistycznych Państwowej Wyższej Szkoły Informatyki i Przedsiębiorczości w Łomży, Katedra Nauk Prawnych

ORCID: 0000-0002-3902-0063

e-mail: aszafranek@pwsip.edu.pl 
